\title{
PELATIHAN KONSELING KARIER CAREER INFORMATION PROCESSING (CIP) BAGI GURU BK SMP KOTA MOJOKERTO
}

\author{
Oleh: \\ Denok Setiawati, S.Pd., M.Pd., Kons, Dr.Budi Purwoko, M.Pd, Drs. M.Nursalim, M.Si dan Dra. Titin Indah Pratiwi, \\ M.Pd. \\ Jurusan Bimbingan dan Konseling, Fakultas Ilmu Pendidikan, Universitas Negeri Surabaya \\ Email :
}

\begin{abstract}
Abstrak
Pengabdian kepada masyarakat ini bertujuan untuk meningkatkankan kompetensi akademik dan kompetensi profesional guru Bimbingan dan Konseling tingkat SMP di Kota Mojokerto. Target yang adalah meningkatkanya pemahaman serta keterampilan memberikan layanan bimbingan dan konseling di bidang karier terutama dalam hal mendampingi siswa dalam program perencanaan individual. Jenis penelitian ini adalah penelitian deskriptif dengan metode pengumpulan datanya adalah teknik wawancara dan angket terbuka. Subyek penelitian adalah 44 guru BK. Adapun teknik analisis data yang digunakan adalah teknik prosentase. Kompetesi yang dilatihkan adalah softskills berupa pelayanan di bidang karier yag berorientasi pada pendekatan CIP...Metode yang digunakan dalam PKM adalah pelatihan kepada guru Bimbingan dan Konseling dalam waktu tertentu dengan menggunakan siklus Communication, Analysis, synthesis, Valuing, dan Execution (CASVE) berfungsi sebagai suatu basis untuk membantu para konseli dengan pengambilan keputusan. Hasil pelatihan dengan menggunakan instrument angket terbuka menunjukkan adanya peningkatan kompetensi guru Bimbingan dan Konseling sebesar $91 \%$. Sedangkan untuk pelaksanaan pelatihan, pelatihan ini mendapatkan skor rata-rata 3,36 atau $84 \%$ atau masuk kategori sangat berguna dan 3,24 atau $81 \%$ memenuhi kriteria kepatutan. Sedangkan untuk peningkatan ketrampilan communication meningkat 88,24\%, Analysis 85,29 \%, synthesis 91,18\%, Valuing 91,18\%, dan Execution 94,12\%.
\end{abstract}

Kata Kunci : Pelatihan, konseling karier career information processing (CIP), guru BK

\begin{abstract}
This community service aims to improve the academic competency and professional competence of the Junior High School Guidance and Counseling teachers in the City of Mojokerto. The target is to increase understanding and skills in providing guidance and counseling services in the career field, especially in terms of assisting students in individual planning programs. The research is descriptive research with collected data method is interview and open questionar. The subject of researched were 44 counseling teachers present. Analysys data technique used precentage technique. The training being trained is soft skills in the form of services in the career field that are oriented towards the CIP approach. The method used in PKM is training for Guidance and Counseling teachers at certain times using the cycle of Communication, Analysis, synthesis, Valuing and Execution (CASVE) functions as a basis to assist counselees with decision making. The results of the training using an open questionnaire instrument showed an increase in the competence of Guidance and Counseling teachers by $91 \%$. As for the training, this training received an average score of 3.36 or $84 \%$ or was in a very useful category and 3.24 or $81 \%$ met the decency criteria. Whereas for communication skills improvement, it increased $88.24 \%$, Analysis $85.29 \%$, Synthesis $91.18 \%$, Valuing 91.18\%, and Execution $94.12 \%$.
\end{abstract}

Keywords: Training, career information processing (CIP) career counseling, guidance and counseeling teachers 


\section{PENDAHULUAN}

Sosok utuh kompetensi konselor terdiri atas 2 komponen yang berbeda namun terintegrasi dalam praksis sehingga tidak dapat dipisahkan yaitu kompetensi akademik dan kompetensi professional, (Depdiknas, 2007). Kompetensi akademik seorang Konselor Profesional terdiri atas kemampuan: 1) Mengenal secara mendalam konseli yang hendak dilayanai; 2) Menguasai khasanah teoritik dan prosedural serta teknologi dalam bimbingan dan konseling. Kompetensi profesional konselor terbentuk melalui latihan dalam menerapkan komptensi akademik dalam bimbingan dan konseling. Pembentukan kompetensi konselor dapat dibentuk melalui proses penyiapan calon konselor (mahasiswa) dalam pendidikannya. Namun ternyata kompetensi-kompetensi di atas belum sepenuhnya bisa dikuasai oleh para konselor di sekolah.

Berdasarkan data hasil asesmen kebutuhan dengan MGBK SMP kota Mojokerto, didapatkan data sebagai berikut; (1) kurang optimalnya pelayanan Bimbingan dan Konseling yang berorientasi pada teori atau pendekatan tertentu terutama di bidang karier; (2) kurang optimalnya pelayanan Bimbingan dan Konseling di Bidang Karier; (3) belum optimalnya pelayanan peminatan karier sesuai bakat dan minat siswa.

Kurang optimalnya pelayanan Bimbingan dan Konseling yang berorientasi pada teori terutama di bidang karier karena mereka belum menguasai satu strategi khusus (yang berorientasi pada teori tertentu) untuk membantu siswa/konseli dalam menyelesaikan permasalahan karier. Guru Bimbingan dan Konseling masih mengandalkan layanan klasikal atau informasi atau menggunakan cara konvensional seperti; pemberian nasehat atau reinforcement. Ada banyak hal yang menyebabkan guru Bimbingan dan Konseling belum bisa optimal melakukan konseling dengan pendekatan tertentu diantaranya: kurangnya updating informasi tentang teori yang sedang berkembang, kurang terampil dalam memahami dan mempraktikkan.

Permasalahan kedua yang dihadapi adalah kurang optimalnya pelayanan Bimbingan dan Konseling di Bidang Karier. Kompleksitas masalah remaja menjadikan para guru BK lebih menekankan pada layanan di bidang lain misalnya pribadi-sosial sehingga karier kurang terperhatikan atau dianggap selesai dengan siswa bisa memilih SMA dan SMK tanpa proses berpikir yang matang dan tidak dihubungkan dengan pemilihan pekerjaan yang lebih baik. Padahal, kurangnya pelayanan siswa pada bidang karier menjadikan peserta didik kurang mampu merencanakan masa depannya dengan baik.

Permasalahan ketiga yakni belum optimalnya pelayanan peminatan karier sesuai bakat dan minat siswa dalam bingkai komponen perencanaan indiviual. Kurikulum 2013 menekankanpada peminatan siswa. Layanan peminatan menjadi salah satu sarana untuk menemukan potensi siswa dan mengarahkan pada karier yang tepat. Di kota Mojokerto telah diberikan layanan peminatan, namun masih belum dilaksanakan dengan optimal. Hal ini terlihat adanya siswa yang masih bingung dalam menentukan pekerjaan profesial dan pilihan jurusan sekolah yang selaras dengan pilihan pekerjaan. Harus dipahami bahwa pelayanan bimbingan dan konseling di sekolah menengah merupakan setting yang paling subur bagi konselor, karena di jenjang itulah konselor dapat berperan secara maksimal dalam memasilitasi konseli mengaktualisasi potensi yang dimilikinya secara optimal, (Depdiknas, 2007). Beberapa kasus yang terjadi pada siswa SMP karena perkembangan mereka belum terfasilitasi dengan baik, termasuk didalamnya adalah wawasan dan kesiapaan karier.

Kondisi ini, tentu saja tidak boleh dibiarkan apalagi konseli sebagai individu yang sedang berada dalam proses berkembang atau menjadi (on becoming), yaitu berkembang ke arah kematangan atau kemandirian (Depdiknas, 2007). Butuh ada penyelesaian, salah satunya adanya dengan adalah pelatihan konseling karier dengan pendekatan career information processing (CIP).

Pemecahan masalah karir perspektif teori kognitif dapat ditelusuri dari pekerjaan Frank Parsons, yang menjelaskan tiga faktor kunci dalam membuat pilihan karir. Ketiga faktor kunci tersebut adalah (1) pengetahuan diri; (2) pengetahuan tentang pekerjaan; dan (3) kemampuan untuk menarik hubungan antara keduanya. Parsons beralasan bahwa jika individu memiliki atribut ini, mereka tidak hanya akan membuat pilihan yang tepat bagi diri mereka sendiri tetapi juga fungsi produktif masyarakat akan lebih besar pada orang yang memiliki kecocokan pekerjaan. Ketiga faktor tersebut sekarang diwakili dalam teori CIP dengan domain pengetahuan diri, domain pengetahuan kerja, dan domain keterampilan pengambilan keputusan (Peterson dkk., 2002).

Tujuan pendekatan CIP adalah untuk membantu individu-individu membuat suatu pilihan karir yang tepat, dan belajar meningkatkan keterampilan pemecahan masalah dan pengambilan keputusan karir yang diperlukan untuk pilihan-pilihan di masa mendatang. Pendekatan CIP memungkinkan para konselor untuk secara terus-menerus menangani permasalahanpermasalahan karir konseli saat ini dan juga mengajari mereka keterampilan-keterampilan untuk membuat keputusan-keputusan karir selama rentang kehidupannya (Peterson dkk., 2002). Selain itu teori CIP berfokus pada bagaimana membuat keputusan karier, daripada menekankan pada hasil keputusan. Teori ini dirancang untuk membantu siswa membuat pilihan karier yang tepat pada saat ini, sekaligus belajar meningkatkan kemampuan dalam menyelesaikan masalah dan pembuatan keputusan yang akan dibutuhkan oleh siswa di masa depan, (Sampson etc, 2004). erdasarkan analisiss situasai yang ada, maka diadakanlah pelatihan konseling karier career information processing (CIP) bagu guru BK SMP kota Mojokerto.

\section{METODE}

Berdasarkan hasil asesmen kebutuhan dengan mitra, disepakati untuk mengatasi permasalahan yang terjadi dengan melakukan sebuah pelatihan. Prosedur pelaksanaan pengabdian kepada masyarakat antara lain 
analisis kebutuhan mitra dengan teknik wawancara. Selanjutnya bersama mitra mengidentifikasi permasalahan yang dihadapi oleh mitra dalam melakukan pelayanan Bimbingan dan Konseling. Hal ini dilakukan untuk dapat memberikan solusi yang tepat sehingga mampu membantu menyelesaikan permasalahan mitra. Dalam hal ini adalah adanya permasalah pada kompetensi membei layanan konseling yang berorientasi pada bidang karier.

Subyek pelatihan adalah para guru BK SMP di kota Mojokerto yang berjumlah 44 orang dengan rincian sebagai berikut:

Tabel 3 Rincian asal sekolah peserta

\begin{tabular}{|c|c|c|}
\hline No. & Asal Sekolah & $\begin{array}{l}\text { Jumlah } \\
\text { Peserta }\end{array}$ \\
\hline 1. & SMPN 1 Kota Mojokerto & 3 orang \\
\hline 2. & SMPN 2 Kota Mojokerto & 4 orang \\
\hline 3. & SMPN 3 Kota Mojokerto & 3 orang \\
\hline 4. & SMPN 4 Kota Mojokerto & 5 orang \\
\hline 5. & SMPN 5 Kota Mojokerto & 2 orang \\
\hline 6. & SMPN 6 Kota Mojokerto & 4 orang \\
\hline 7. & SMPN 7 Kota Mojokerto & 3 orang \\
\hline 8. & SMPN 8 Kota Mojokerto & 3 orang \\
\hline 9. & SMPN 9 Kota Mojokerto & 2 orang \\
\hline 10. & $\begin{array}{l}\text { SMP Islam Brawijaya } \\
\text { Mojokerto }\end{array}$ & 4 orang \\
\hline 11. & SMPIT Permata Mojokerto & 1 orang \\
\hline 12. & $\begin{array}{l}\text { SMP Muhammadiyah } 1 \\
\text { Mojokerto }\end{array}$ & 1 orang \\
\hline 13. & SMP PGRI 1 Mojokerto & 1 orang \\
\hline 14. & SMP Katolik Mojokerto & 1 orang \\
\hline 15. & SMP TNH Mojokerto & 2 orang \\
\hline 16. & SMP Taman Siswa Mojokerto & 2 orang \\
\hline 17. & SMP Darul Qur'an Mojokerto & 1 orang \\
\hline 18. & SMP Al-Azhar Mojokerto & 1 orang \\
\hline 19. & MTs Nurul Jadid Mojokerto & 1 orang \\
\hline & Jumlah & 44 orang \\
\hline
\end{tabular}

Selanjutnya yakni memberikan pelatihan konseling karier CIP dengan metode CASVE. CASVE adalah akronim dari communication, analysis, sinthesis, valuing dan execution. Teknik pengumpulan data dilakukan dengan menggunakan teknik wawancara dan angket terbuka sedangkan untuk teknik analisis datanya adalah analisis prosentase.

\section{HASIL DAN PEMBAHASAN}

Pelatihan konseling karier Career Information Processing (CIP) bagi Guru BK SMP di Kota Mojokerto dilaksanakan dalam dua pertemuan. Pertemuan pertama dilaksanakan pada hari Rabu,15 Agustus 2018 jam 08.0015.00 WIB bertempat di SMPN 8 Kota Mojokerto. Sedangkan, pertemuan kedua dilaksanakan pada hari Kamis, 23 Agustus 2018 jam 08.00-12.00 WIB dengan tempat yang sama. Peserta yang berpartisipasi sejumlah 44 orang.

Pelatihan pertemuan pertama terbagi dalam empat sesi yaitu: (1) konseling karier; (2) pendekatan- pendekatan konseling karier; (3) konseling karier CIP.dan konseling karier CIP dengan metode CASVE. Adapun rincian kegiatannya adalah sebagai berikut.a.

\section{Communication}

Proses yang terjadi pada tahapan ini adalah ada upaya menanyakan pada diri sendiri dan lingkungan untuk mengidentifikasi kesenjangan antara keadaan yang ada dan keadaan yang lebih diinginkan, daya motivasi untuk mencari resolusi untuk masalah. Pada tahap ini konselor diminta untuk memberikan salah satu contoh pekerjaan atau profesi yang dimilih, untuk selanjutkan diminta untuk mengidentifikasi kesenjangan yang terjadi dengan kata lain mengidentifikasi antara keinginan dengan realita.

Identifikasi terhadap kesenjangan menciptakan ketegangan (disebut disonansi kognitif) yang menyediakan sumber daya motivasi untuk mencari resolusi untuk masalah karir (Festinger, 1964 dalam Peterson,2002).

2. Analysis

Langkah selanjutnya adalah konselor melakukan analisis. Kegiatan yang dilakukan adalah pengidentifikasian penyebab masalah dan berhubungan dengan komponen-komponen masalah ditempatkan dalam kerangka konseptual. Yang dimaksud adalah mengidentifikasi penyebab masalah yang terjadi pada tahap communication.

3. Synthesis

Dua proses yang dilakukan pada tahap ini adalah yaitu elaborasi dan kristalisasi. Perumusan kemungkinan program aksi yang melalui dua proses, yaitu elaborasi dan kristalisasi. Elaborasi terkait berbagai solusi yang mungkin, bahkan yang tidak mungkin. Sedangkan Kristalisasi adalah penyempitan pilihan potensial untuk satu perangkat alternatif yang layak melalui penerapan konstruksi pribadi.

4. Valuing

Tahapan penilaian mencakup evaluasi dari alternatif-alternatif, menentukan kelangsungan hidup pilihan yang potensial, dan memprioritaskan kesempatan karir. Selama tahapan ini, para konselor diminta secara cermat memperhatikan bagaimana nilai-nilai mereka berinteraksi dengan pilihan-pilihan karir.

5. Execution

Tahap eksekusi, melibatkan upaya memunculkan suatu rencana aksi (action plan) untuk menutup gap/kesenjangan dan mengejar pilihan pertama konseli ke arah pengembangan karir dan gaya hidup yang diharapkan.

Tahap terakhir ini memerlkan perenungan dan peninjauan proses pemecahan masalah itu sendiri untuk meningkatkan keterampilan pemecahan masalah karir berikutnya atau bahkan generalisasi untuk masalah kehidupan nyata lainnya.

Sesi akhir pertemuan pertama, peserta diberi pengarahan untuk mempraktekkan pengetahuan dan keterampilan konseling karier CIP metode CASVE di sekolahnya masing-masing. Setiap peserta diharapkan 
menangani masalah satu konseli dengan metode CASVE. Pelaksanaan konseling tersebut akan dibahas pada pelatihan pertemuan kedua.

Pelatihan pertemuan kedua dilaksanakan seminggu kemudian. Targetnya yaitu evaluasi dan tindak lanjut pelaksanaan Masing-masing peserta melaporkan hasil praktek di sekolahnya serta menyampaikan hambatan yang dihadapi.

Hasil pelatihan dengan menggunakan instrument angket terbuka menunjukkan adanya peningkatan kompetensi guru Bimbingan dan Konseling sebesar $91 \%$. Sedangkan untuk pelaksanaan pelatihan skor rata-rata 3,36 atau $84 \%$ atau masuk kategori sangat berguna dan 3,24 atau $81 \%$ memenuhi kriteria kepatutan. Sedangkan untuk rincin hasil pelatihan per tahapan adalah sebagai berikut:

Tabel Hasil Pelatihan

\begin{tabular}{|l|l|}
\hline Metode CASVE & Hasil \\
\hline Communication & $88,24 \%$ Meningkat \\
& $11,76 \%$ Belum Meningkat \\
\hline Analysis & $85,29 \%$ Meningkat \\
& $14,71 \%$ Belum Meningkat \\
\hline Sinthesis & $91,18 \%$ Meningkat \\
& $8,82 \%$ Belum Meningkat \\
\hline Valuing & $91,18 \%$ Meningkat \\
& $8,82 \%$ Belum Meningkat \\
\hline Execution & $94,12 \%$ Meningkat \\
& $5,82 \%$ Belum Meningkat \\
\hline
\end{tabular}

Secara umum terjadi peningkatan pada seluruh keterampilan. Hanya saja peningkatan terjadi secara signifikan pada ketermpilan mengeksekusi. Belum atau tidak menigkatnya keterampilan disebabkan karena beberapa guru BK belum mampu menguasai maksud metode CASVE. Padahal, penguasaan materi berhubungan dengan penguasaan kompetensi akademik dalam hal menguasai khasanah teoritik BK, (Depdiknas, 2007). Apabila kompetensi akademik sudah terkuasai maka pembentukan kompetensi profesional bukanlah hal yang sulit.

Prosentase terendah ada di kemampuan Analysis. Kemampuan menganalisis dapat diartikan sebagai kemampuan individu untuk menentukan bagian-bagian dari suatu masalah dan menunjukkan hubungan antar-bagian tersebut, melihat penyebab-penyebab dari suatu peristiwa atau memberi argumen-argumen yang menyokong suatu pernyataan, (Sudrajat, 2011).

Pasca pelatihan dilaksanakan, peserta diminta mengisi angket kepuasan/ evaluasi dan umpan balik pelatihan konseling karier CIP metode CASVE. Evaluasi ini untuk mengukur keberhasilan pelatihan. Hasil evaluasi pelatihan tersaji pada tabel berikut.

Tabel Evaluasi hasil pelatihan

\begin{tabular}{|l|l|l|}
\hline No. & Aspek/ Indikator & \\
\hline 1. & Kebermanfaatan & $58,82 \%$ \\
& pelatihan bagi & Bermanfaat \\
& konselor & $41,18 \%$ Sangat \\
\hline
\end{tabular}

\begin{tabular}{|c|c|c|}
\hline & & bermanfaat \\
\hline 2. & \begin{tabular}{l}
\multicolumn{2}{l}{ Kebermanfaatan } \\
pelatihan dalam \\
membantu konselor \\
memberikan pelayanan
\end{tabular} & $\begin{array}{l}52,94 \% \text { Sangat } \\
\text { bermanfaat } \\
47,06 \% \\
\text { Bermanfaat }\end{array}$ \\
\hline 3. & \begin{tabular}{lr}
\multicolumn{2}{l}{ Materi pelatihan sesuai } \\
dengan kebutuhan \\
siswa SMP
\end{tabular} & $\begin{array}{l}\begin{array}{l}61,76 \% \\
38,24 \%\end{array} \text { Sesuai } \\
\begin{array}{l}\text { sesuai } \\
\text { sat }\end{array}\end{array}$ \\
\hline 4. & $\begin{array}{l}\text { Materi pelatihan dapat } \\
\text { membantu siswa SMP } \\
\text { memenuhi standar } \\
\text { kemandirian }\end{array}$ & $\begin{array}{l}85,29 \% \\
\text { Memenuhi } \\
\text { 14,71\% Sangat } \\
\text { memenuhi }\end{array}$ \\
\hline
\end{tabular}

\section{SIMPULAN DAN SARAN}

\section{Simpulan}

Berdasarkan pembahasan pada bab-bab sebelumnya, maka simpulan yang dapat dibuat antara lain:

a. Secara umum terjadi peningkatan pada seluruh keterampilan communication meningkat $88,24 \%$, analysis meningkat $85,29 \%$, sinthesis meningkat $91,18 \%$, valuing meningkat $91,18 \%$ dan execution meningkat $94,12 \%$.

b. Pendekatan konseling karier yang dibutuhkan oleh mitra yaitu konseling karier Career Information Processing (CIP).

c. Sebelum pelatihan dilaksanakan, tim pelaksana menyusun buku panduan Konseling Karier Career Information Processing (CIP).

d. Pelatihan dilakukan dalam dua kali pertemuan.

e. Evaluasi hasil pelatihan menunjukkan adanya kepuasaan peserta terhadap pelaksanaan pelatihan.

\section{Saran}

Berdasarkan simpulan di atas, maka hal-hal yang menjadi saran yaitu:

a. Setiap pelatihan membutuhkan persiapan dan sosialisasi yang baik.

b. Evaluasi hasil pelatihan perlu dilakukan secara periodik dan berkala.

\section{DAFTAR PUSTAKA}

Brown, D. 2007. Career Information, Career Counseling, and Career Development. USA: Pearson Education, Inc.

Clemens, E.V. \& Milsom, A.S. 2008. Enlisted Service Members Transition Into the Civilian World of Work: A Cognitive Information Processing Approach. The Career Development Quarterly, 56: 246-256

Departemen Pendidikan Nasional. (2007). Penataan Pendidikan Profesional Konselor dan Layanan Bimbingan dan Konseling dalam Jalur Pendidikan Formal. Jakarta: Departemen Pendidikan Nasional 
McLennan, N.A. \& Arthur, N. 1999. Applying the Cognitive Information Processing Approach to Career Problem Solving and Decision Making to Women's Career Development. Journal of Employment counseling, 36: 82-96.

Peterson, G.W., dkk. 2002. A Cognitive Information Processing Approach to Career Problem Solving and Decision Making (D. Brown \& Associates, Ed.). San Francisco: John Wiley \& Sons, Inc.

Reardon, R.C. \& Wright, L.K. 1999. The Case of Mandy: Applying Holland's Theory and Cognitive Information Processing Theory. The Career Development Quarterly, 47: 195-203.

Sampson, J.P., dkk. 1999. A Cognitive Information Processing Approach to Employment Problem Solving and Decision Making. The Career Development Quarterly, 48: 3-18.

Sampson, J.P., dkk., 2000. Using Readiness Assessment to Improve Career Services: A Cognitive Information-Processing Approach. The Career Development Quarterly, 49: 146-174.

Sampson, J. P. Jr., \& Reardon, R. C., Peterson, G. W., Lenz, J. G. 2004. Career Counseling \& Services (A Cognitive Information Processing Approach).California:Brooks/Cole-Thomson Learning

Setio Rini, Fuaidah dan Denok Setiawati. 2018. Pengembangan Buku Panduan Persiapan karier Model Cognitive Information Processing (CIP) untuk Siswa kelas XI SMK Dharma Wanita Gresik. Jurnal BK Unesa, Vol 8 No.2 tahun 2018.

Wahab, Abdul dan Lestari, Lies Amin. 1999. Menulis Karya Ilmiah. Surabaya: Airlangga University Press.

Winardi, Gunawan. 2002. Panduan Mempersiapkan Tulisan Ilmiah. Bandung: Akatiga. 